\title{
Transmission of Cucumber Mosaic Virus (CMV) infecting banana by aphid and mechanical methods
}

\author{
R. Dheepa ${ }^{*}$ and S. Paranjothi \\ Department of Biotechnology, M.G.R College, Hosur, Krishnagiri (District), \\ Tamil Nadu, India
}

\begin{abstract}
Banana is the premier fruit of the Asia and pacific region. It is the fourth most important food crop after rice, wheat and maize. In Tamil Nadu, banana is grown in 92,200 hectares with an annual production of 48.56 million tones. Among all biotic constraints, viruses cause huge economic loss to the crop. Some of the major diseases are caused by viruses which include Banana Bunchy Top Virus (BBTV), Cucumber Mosaic Virus (CMV), Banana Streak Virus (BSV), Banana Bract Mosaic Virus (BBMV) have been reported in our country. CMV virus concentration in host (Musa) tissue is very less. So it is necessary to transfer this virus to good propagation host such as Nicotiana sp for purification. The purpose of the study was the transmission of CMV infecting banana into propagation host either by aphid or mechanically. The transmission was confirmed through Direct Antigen Coating Enzyme Linked Immuno Sorbent Assay (DAC-ELISA).
\end{abstract}

Keywords: Cucumber Mosaic Virus, transmission, aphid method, mechanical method, Direct Antigen Coating ELISA.

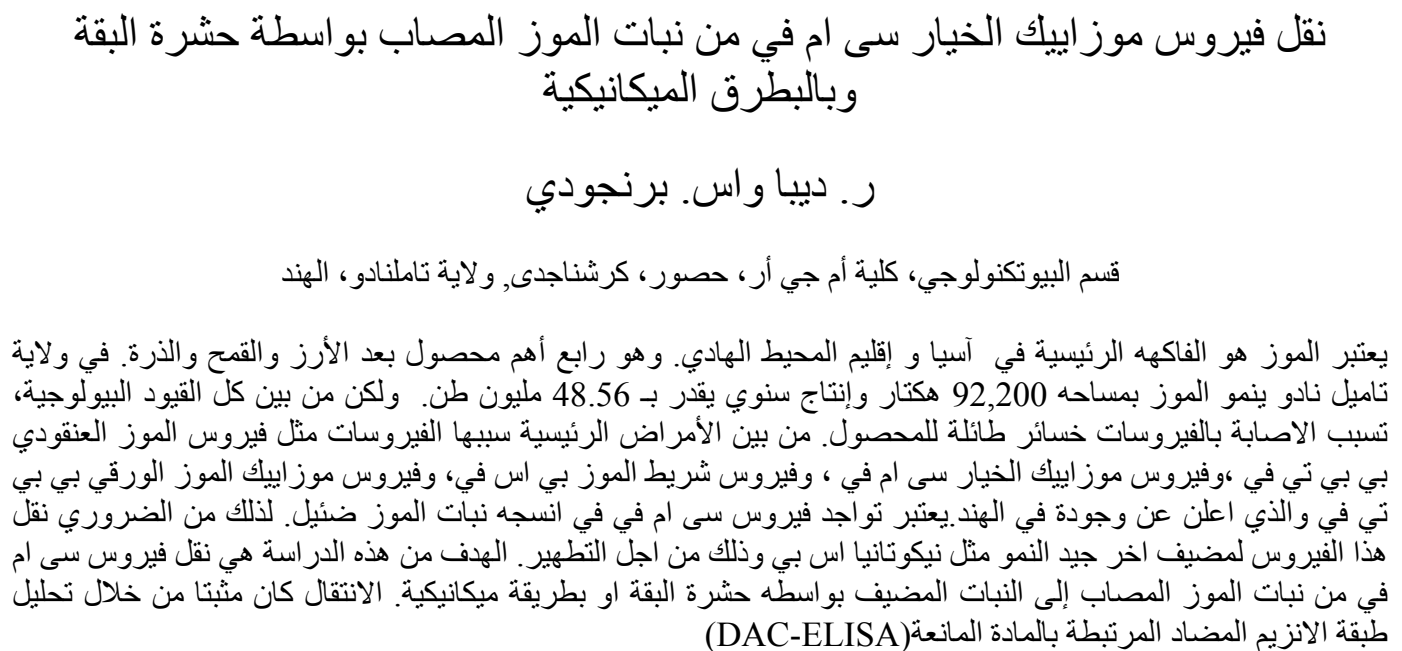

\section{Introduction}

Banana is the premier fruit of the Asia and pacific region. It is the fourth most important food crop after rice, wheat and maize. World production of bananas is around 70 million tonnes, with plantation of 30 million tonnes. Nearly half the world production of banana comes from Asia. Worldwide, 4.5 million hectares are devoted to banana cultivation. Approximately 98 per cent of world production is grown in developing countries. More than 73 per cent of total banana production is contributed by ten major banana-producing countries. India, Ecuador, Brazil and China alone produce half of total banana output.

India's share is around 24 per cent. Global banana trade is currently estimated at $\$ 4.7$ billion. India is the biggest producer of bananas with 17 million 
tones. The major banana growing states are Maharashtra, Tamil Nadu, Gujarat, Assam, Karnataka, Kerala, Bihar, West Bengal, Andhra Pradesh, Orissa and Madhya Pradesh. Banana and plantains are good source of dietary carbohydrates; vitamins $\mathrm{C} \& \mathrm{~B} 6$ and minerals but is fatfree and low in proteins. It has several medicinal properties (Simmonds, 1966). Fruits are good for the treatment of gastric ulcer, diarrhoea, cancer and heart diseases. Banana is widely grown under tropical and subtropical conditions.

Biotic factors caused by pests and diseases present constant threats to banana farmers. Biotic stresses like fungi, bacteria, nematodes, viruses and insect pests limit the production and productivity of banana. Among all biotic constraints, viruses cause huge economic loss to the crop. Bananas are affected by four known, relatively well-characterized viruses (Diekmann and Putter, 1996) these are Banana bunchy top virus (BBTV) genus Nanavirus, Banana streak virus (BSV) genus Badnavirus; Cucumber mosaic virus (CMV) genus Cucumovirus; and Banana bract mosaic virus (BBrMV) genus Potyvirus. Recently, a filamentous virus, Banana mild mosaic virus (BanMMV), (Thomas et al., 2000; Gambley and Thomas, 2001) has been shown to be widespread in banana and also been noted in bananas from Africa, the Americas, Southeast Asia, and Australia (Lockhart and Jones, 1995; Thomas et al., 2000) (Figures 1 and 2).

Banana bunchy top virus has wiped out the hill banana in Tamilnadu. A loss of about 80 million USD annually has been recorded due to BBTV in kerala (Metha et al., 1964). Banana bract mosaic and streak viral diseases of recent origin caused huge economic loss. The most of the commercial cultivars are known to be infected by BBMV. A hardy banana, Poovan grown throughout India has been a victim for BSV. CMV is still assuming importance in all the banana growing regions of India.
In India, the occurrence of CMV has been reported from many hosts such as Egyptian henbane (Samad et al., 2000), gladiolus (Raj et al., 2002), Lycopersicum esculentum (Sudhakar et al., 2006), Geranium (Verma et al., 2006), banana (Aglave et al., 2007), Rauvolfia serpentina and Jatropha curcas (Raj et al., 2007, 2008). However, only limited reports are available on biological and molecular characteristics of these isolates (Madhubala et al., 2005, Verma et al., 2004, 2006). CMV causes chlorosis, mosaic and heart rot in banana and has been found in most banana growing areas of the world.

Viral diagnosis of a virus infection in plants is the easy method of detection. Banana viruses known to exist in latent form without expressing any visual symptoms for long time. If mother plants used for mass multiplication are nit indexed, the virus can easily pass through to the progenies. Hence it is a need to standardize and develop serodiagnostic techniques to identify the viruses, if they are in latent form.

The field identification of viral diseases caused by BBTV, BBMV, BSV and CMV based on the symptoms in banana and plantains is difficult at certain stages of disease development. Symptoms are of limited value in certain condition for the identification of the causative viral agent. Identification of the viruses by serological methods will be of more accurate, reliable, less time consuming and also cost effective. Banana is infected by several viral diseases of which Banana bunchy top virus; Banana bract mosaic virus, Banana streak virus and cucumber mosaic virus are the most serious viral diseases and have devastating effect on the cultivation of banana. Recently a new Banana mild mosaic virus has been reported by (Thomas et al., 1994). 
Emir. J. Food Agric. 2010. 22 (2): 117-129

http://ffa.uaeu.ac.ae/ejfa.shtml

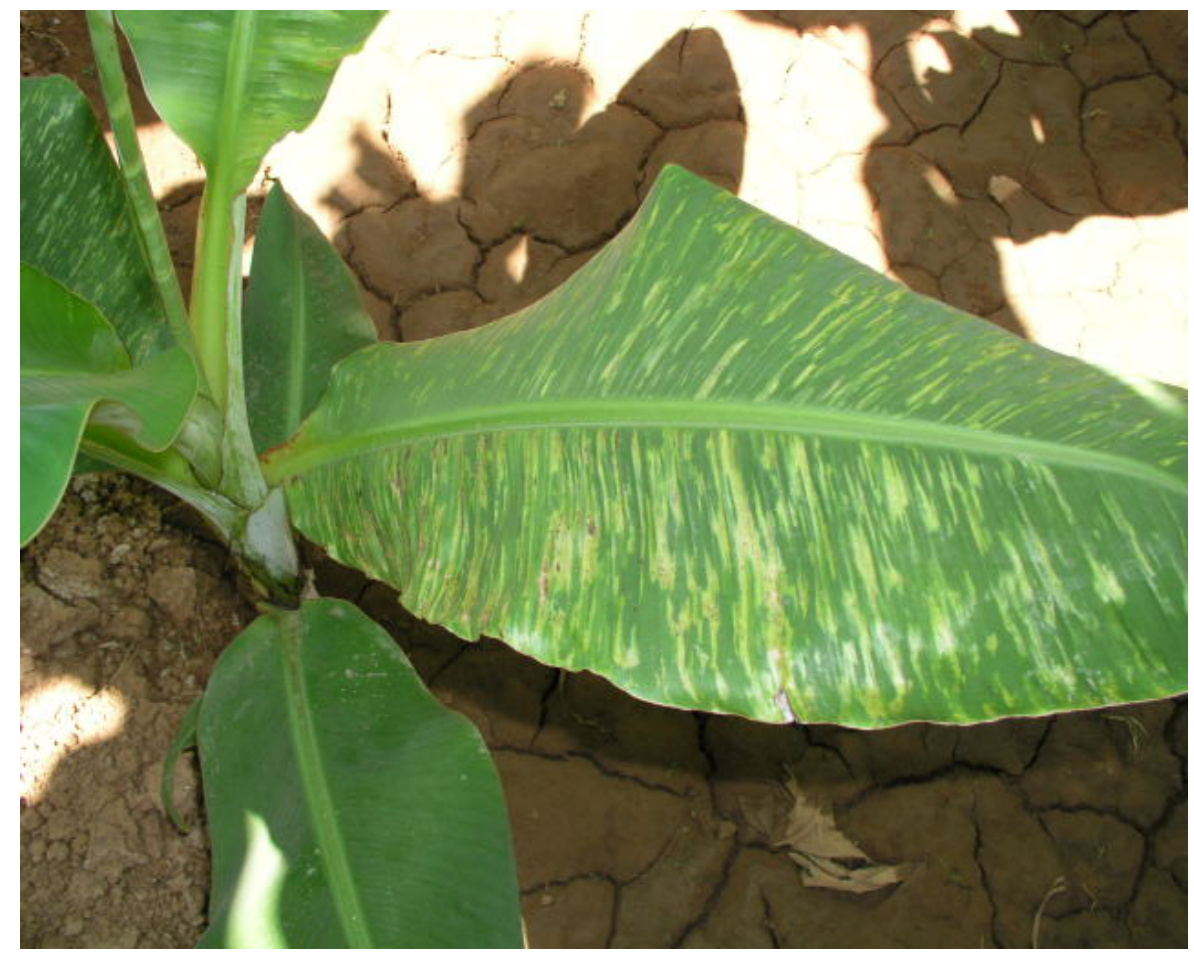

Figure 1. Cucumber Mosaic Virus (CMV) infected Banana plant.

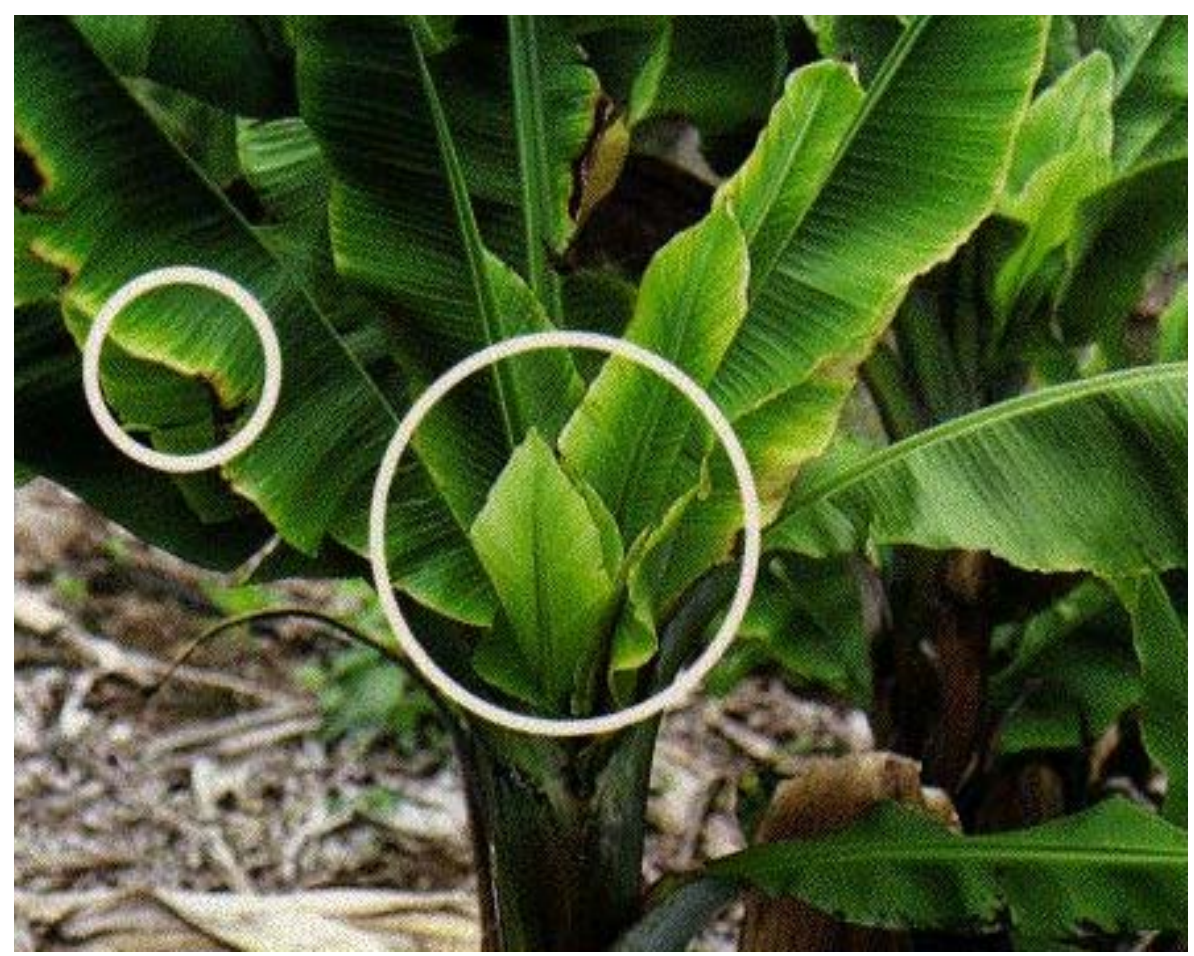

Figure 2. Banana Bunchy Top Virus (BBTV) infected plant. 
CMV causes great losses in vegetables, ornamentals and fruits, and it is destructive due to its rapid spread by more than 60 aphid species in the field (Palukaitis and Garcia-Arenal, 2003). Transmission through planting material is also significant in some crop and weed hosts (Hsu et al., 2000).

Banana mosaic or infectious chlorosis is one of the important and widely distributed viral diseases of banana. Banana mosaic is cosmopolitan, and is found wherever bananas are grown. This virus is a member of the cucumovirus group and belongs to bromoviridae. CMV is easily transmitted by sap inoculation and by aphids in a non- persistent manner (Kaper et al., 1981). In some virus infections, the whole leaf may become chlorotic due to decreased chlorophyll production and the breakdown of chloroplasts.

CMV, which has alternate host and can be readily, transferred by a member of insects vectors in a non - persistent manner (Bird and Wellman, 1962). Banana mosaic disease is transmitted successfully by Aphis gossypii and poorly by Aphis craccivora but not at all by Pentalonia nigronervosa in Puerto Rico. Shukla and Govinda (2000) made a detailed study to establish virus- vector relationship of aphid of CMV. He showed that a short preacquisition fasting (2hrs) and acquisition threshold ( $2 \mathrm{~min}$ ) given to $A$. pisum increased the efficiency of the aphid and that a single aphid can produce infection, although in low percentage and the percentage infection increases with an increase in the number of aphids.

Banana bunchy top is another serious virus found to reduce the banana production in India. Dale (1987) reported that the virus is present round the year in hill area but less significant in plains. BBTV spreads via undetected infection in suckers and the secondary spread is through the banana aphid, Pentalonia nigronervosa in a semi- persistent manner (Magee, 1927, 1940). Attempts on mechanical transmission of BBTV have failed (Magnaye and Valmayor, 1995). $\mathrm{CMV}$ is transmitted in the non-persistent manner by several aphid species (Mali and Rajgore, 1980; Palukaitis and GarciaArenal, 2003).

Even though CMV infecting other than banana can be transferred to many hosts for the purpose of propagation and purification, it is always difficult to transmit the CMV banana isolate to propagation hosts either mechanically through sap or by aphid vectors. Considering the importance of banana and its viral pathogens, the present investigations were undertaken with a main objective of diagnosing viruses through serodiagnostic techniques such as Enzyme Linked Immuno Sorbent Assay (ELISA), Dot Immuno Binding Assay (DIBA) and Electro Blot Immuno Assay (EBIA). To accomplish the above objective, the studies on collection, maintenance of virus culture; transmission, host range and detection of CMV infecting banana were performed.

\section{Materials and Methods}

The present investigations were undertaken to identify the causal virus based on transmission and serological testing. The research work has been carried out at Molecular Virology Laboratory, National Research Center for Banana (NRCB), Indian Council of Agricultural Research, Tiruchirappalli, Tamil Nadu, India.

\section{Maintenance of virus}

The Banana Mosaic Virus, symptomatic samples collected were maintained at $28^{\circ} \mathrm{C}$ in the insect proof glass house at NRCB, farm. Healthy plants were also maintained in the same glass house.

\section{Maintenance of other hosts}

For mechanical sap inoculation and transmission through aphid species were done on Commelina sp, Nicotiana glutinosa, Vigna radiata, Vigna mungo and 
Chenopodium spp in addition to banana. The experimental hosts were raised through seed and maintained in 10-inch pots with standard pot mixture.

\section{Maintenance of aphids}

Three aphid species such as Aphis craccivora maintained in cowpea, Aphis gossypii maintained in cotton seedlings and Pentalonia nigronervosa, the banana black aphid was multiplied in small healthy banana plants in separate room.

\section{Methods of transmission \\ Mechanical transmission}

For transmission and host range studies, mechanical inoculations were carried out by extracting banana tissues infected with CMV in $0.1 \mathrm{M}$ phosphate buffer, $\mathrm{pH} 7.0$ containing $1.0 \%$ sodium sulphite $(1: 2 \mathrm{~W} / \mathrm{V})$. The infectious sap was applied to healthy Commelina sp, Nicotiana glutinosa, Vigna radiata, Vigna mungo and Chenopodium spp in addition to banana. Leaves of the inoculated plants were previously dusted with 400 mesh carborandum. For control treatment carborundum dusted leaves were inoculated with phosphate buffer alone. Inoculated plants were maintained in the greenhouse at $25-30^{\circ} \mathrm{C}$ for 30 days and the plants were inspected daily for symptom development. The inoculated plants were serologically tested using CMV antiserum.

\section{Aphid transmission}

Individuals of the aphids Aphis gossypii collected from cotton plants and A. craccivora collected from cowpea. Individuals of insect were reared onto healthy cotton and cowpea seedlings. New generation of aphids were transferred to other healthy plants of cotton and cowpea growing in insect proof cages and the aphids were left for reproduction. Several virus free adults of each of the above mentioned aphids were starved for two hours.
They were allowed to feed for $20 \mathrm{~min}$ (acquisition period). After that the aphids were transferred to healthy Commelina sp, Nicotiana glutinosa, Vigna radiata, Vigna mungo and Chenopodium spp in addition to banana allowed to feed for 10-15 min. (inoculation period), and then the insects were sprayed by insecticide (Malathion) The plants were maintained in insect proof cage at $25-30^{\circ} \mathrm{C}$ for 30 days and the plants were inspected daily for symptoms development.

\section{Serodiagnosis of CMV DAC-ELISA}

DAC- ELISA test was performed as described by Clark and Joseph (1984) to test the presence of CMV in collected plants using CMV antiserum.

One-gram midrib portion of leaf sample collected and ground in liquid nitrogen. One $\mathrm{ml}$ of $0.2 \mathrm{M}$ potassium phosphate buffer with $0.5 \%$ sodium sulphite and $1 \%$ polyvinyl pyrolidone (PVP) was added. The sample squeezed gently with absorbent cotton and equal volume of chloroform was added and vortexed thoroughly. The homogenate was centrifuged at 5000rpm for $5 \mathrm{~min}$ and the supernatant was used for coating the ELISA plates.

\section{Source of antiserum}

Cucumber Mosaic Virus antiserum provided by Dr. Ishwar Bhat, Senior Scientist, IISR, Calicut, Kerala, India was used for serodiagnosis study.

Plates were coated with $200 \mu \mathrm{l}$ of partially purified viral antigen sample and incubated at $37^{\circ} \mathrm{C}$ for $1 \mathrm{hr}$ or over night at $4^{\circ} \mathrm{C}$. After incubation, the well's contents were discarded and washed with PBS-T buffer thrice (flooding with PBS-T for $3 \mathrm{~min}$ every time). The blocking solution was added $(200 \mu 1 /$ well $)$ and incubated for $1 \mathrm{hr}$ at $37^{\circ} \mathrm{C}$. After washing the plate (thrice with PBS-T), $200 \mu 1$ of diluted rabbit antiserum (1: 500) was added in the wells and incubated at $37^{\circ} \mathrm{C}$ for $1 \frac{1 / 2}{\mathrm{hrs}}$. 
The plate was washed and $200 \mu 1$ of enzyme conjugate (anti - rabbit alkaline phosphate) was added and incubated at $37^{\circ} \mathrm{C}$ for $1 \frac{1 / 2}{2}$ hrs. After incubation, the plates were washed with PBS-T. After final washing, $200 \mu 1$ of substrate (p-Nitro phenyl phosphate- $0.6 \mathrm{mg} / \mathrm{ml}$ ) was added and allowed for color development at room temperature by avoiding exposure to light. Then the reaction was stopped by adding $3 \mathrm{M} \mathrm{NaOH}$ and the color intensity was read in (Asys Hi-tech ELISA) reader at $405 \mathrm{~nm}$.

\section{Results and Discussion}

\section{Sap Transmission of CMV}

Fifty plants of Tobacco, Chennapodium and $V$. mungo were sap inoculated by using carborundum powder with CMV. The results revealed that Tobacco plants expressed the CMV symptom after three months of inoculation. Transmission of CMV causes severe mosaic and leaf deformations in inoculated plants, which was confirmed through DAC-ELISA.

\section{Aphid Transmission of CMV}

Vector transmission studies using two aphid species Aphis craccivora and A. gossypii, both species are efficiently transmitted the virus in a non-persistent manner within $20 \mathrm{~min}$ of acquisition and inoculation of 10 to $15 \mathrm{~min}$. Thirty plants of Robusta and Tobacco were inoculated with infective Aphis gossypii and thirty plants of Tobacco, Cowpea and Commulina inoculated with infected Aphis craccivora. Some of the Tobacco plants showed the symptoms of CMV after three months of inoculation (Figures 3 and 4). These results revealed that the CMV is aphid transmissible and agreed with the data recorded by Rao (1980) who reported that the successful transmission of CMV to test plants by A. gossypii. Mali and Rajegore (1980) who indicated that CMV isolated from banana was transmitted by A. craccivora to healthy plants.

\section{Serological diagnosis for confirmation of transmission}

This method is very efficient even in detecting symptom less plant. The results revealed that positive control recorded a mean absorbance of 0.358 . The negative control recorded a mean absorbance of 0.148. Among the 18 samples collected from the aphid inoculated plants, only two samples of Tobacco recorded positive result with values similar to that of positive control and the other samples recorded values lower absorbance than that of the positive control (Table 2).

On inoculating two months old healthy plant seedling with virus extract, symptoms appeared on tobacco leaves after 90 days. Out of nine sap inoculated plants only three samples of Tobacco recorded an absorbance similar to the positive control. Except Tobacco the other plants were recorded lower absorbance value, which is similar to that of the negative control at $405 \mathrm{~nm}$, which revealed that CMV was not detected in the following plant spp. Chennapodium and V. mungo (Table 1 and Figure 5).

The present investigation results has clearly revealed the occurrence and association of cucumber mosaic virus with banana chlorosis was identified based on mechanical transmission, insect vector transmission, host range, serology DACELISA detection. The virus was able to transmit mechanically on the plants used in the study very efficiently and produced the systemic and local symptoms characteristic of CMV. In our present study both the aphid species (A. gossypii and $A$. craccivora) transmitted the virus in non persistent manner. Patil (1982) reported that CMV from banana could be transmitted by rhizome inoculation. The ability of CMV to be transmitted declines after about 2 minutes and is usually lost with in 2 hours (Francki et al., 1979). Some investigators (Magee, 1930; Calinisan, 1938; Silberschmidt and Nobrega, 1941) have reported the successful transmission of banana mosaic 
virus by the banana aphid P.nigronervosa, where as others have reported negative transmission (Bird and Wellman, 1962; Mali and Rajegore, 1980). CMV has the broadest host range among the plant viruses (Roosinck, 2002) and has been reported infecting banana and causes banana chlorosis disease. CMV has been identified in other vegetative propagated crops such as Geranium (Verma et al., 2004), Carnation (Raj et al., 1993), Chrysanthemum (Srivastava et al., 1992), based on biological characterization, serological relationship and electron microscopy.

Serology is the most reliable and quick method of detection of CMV infection in banana (Thomas et al., 1991). Presence of CMV in banana can easily be detected by RT-PCR technique (Zora singh et al., 1995). The virus can also be detected by cDNA probe to RNA genome of CMV (Kiranmani et al., 1997). Mali and Rajegore (1980) found that the banana mosaic virus precipitated against the antiserum of CMV using tube ring inter- phase and agar gel diffusion tests. The DAC- ELISA was adopted to detect viruses in plants. It has been reported infecting banana and causes banana chlorosis disease from various parts of the world including Maharashtra (Mali and Deshpande, 1976).

In our study the transmission was confirmed through DAC-ELISA technique. It has been concluded that the transmission of CMV was more successful to $\mathrm{N}$. glutinosa by mechanically and through aphids.

Table 1. Detection of CMV from asymptomatic host plants through DAC-ELISA.

\begin{tabular}{lllllllllllll}
\hline & 1 & 2 & 3 & 4 & 5 & 6 & 7 & 8 & 9 & 10 & 11 & 12 \\
\hline A & N & + & ++ & + & B & + & ++ & + & B & + & + & +++ \\
B & B & + & + & + & B & + & ++ & + & B & + & + & +++ \\
C & N & - & - & - & B & - & - & P & B & - & - & B \\
D & B & - & - & - & B & - & - & N & B & - & - & N \\
E & - & - & - & - & B & - & - & - & - & - & N & - \\
F & - & - & - & - & N & - & - & - & - & - & B & - \\
G & N & P & - & P & Nil & Nil & Nil & Nil & Nil & Nil & Nil & Nil \\
H & B & B & - & B & Nil & Nil & Nil & Nil & Nil & Nil & Nil & Nil \\
\hline
\end{tabular}

N-Negative control, P-Positive control, B- Buffer control

$\mathrm{A}_{2}-\mathrm{A}_{4} \& \mathrm{~B}_{2}-\mathrm{B}_{4}-$ Mechanical Transmission of CMV into Nicotiana glutinosa

$\mathrm{A}_{6}, \mathrm{~A} 7 . \mathrm{A} 11, \mathrm{~B} 6, \mathrm{~B} 7, \mathrm{~B} 11$. Transmission of CMV by Aphis craccivora into Nicotiana glutinosa

$\mathrm{A}_{8}, \mathrm{~A} 10, \mathrm{~A} 12, \mathrm{~B} 8, \mathrm{~B} 10, \mathrm{~B} 12$ - Transmission of CMV by Aphis gossypii into Nicotiana glutinosa

$\mathrm{C}_{2}-\mathrm{C}_{4}, \mathrm{C} 6, \mathrm{C} 7, \mathrm{D} 2-\mathrm{D}_{4}, \mathrm{D} 6, \mathrm{D} 7$. Transmission of CMV by Aphis gossypii into Musa

$\mathrm{C}_{10}, \mathrm{C} 11, \mathrm{D} 10, \mathrm{D} 11-\mathrm{Mech}$ anical transmission of CMV into Chenopodium

$\mathrm{E}_{1}-\mathrm{E}_{4}, \mathrm{E} 6 \& \mathrm{~F}_{1}-\mathrm{F}_{4}, \mathrm{~F} 6$ - Transmission of CMV into Vigna ungulate by Aphis craccivora

$\mathrm{E}_{7}-\mathrm{E}_{10} \& \mathrm{~F}_{7}-\mathrm{F}_{10}-$ Mechanical transmission of CMV into Vigna Mungo

E12,G3 \& $\mathrm{F}_{12}, \mathrm{H}_{3}$-Transmission of CMV by Aphis craccivora in Commelina 
Table 2. OD values recorded in ELISA. The colour developed was read at $405 \mathrm{~nm}$ in the ELISA reader.

\begin{tabular}{|c|c|c|c|c|c|c|c|c|c|c|c|c|}
\hline & 1 & 2 & 3 & 4 & 5 & 6 & 7 & 8 & 9 & 10 & 11 & 12 \\
\hline A & 0.043 & 0.269 & 0.358 & 0.248 & -0.002 & 0.178 & 0.268 & 0.125 & 0.001 & 0.131 & 0.171 & 0.409 \\
\hline B & 0.036 & 0.218 & 0.294 & 0.201 & -0.003 & 0.158 & 0.269 & 0.118 & -0.013 & 0.093 & 0.101 & 0.496 \\
\hline $\mathrm{C}$ & 0.038 & 0.08 & 0.085 & 0.053 & -0.01 & 0.033 & 0.02 & 0.307 & -0.011 & 0.018 & 0.023 & -0.015 \\
\hline D & 0.006 & 0.086 & -0.016 & 0.05 & -0.009 & 0.04 & 0.036 & 0.008 & -0.007 & 0.022 & 0.065 & 0.015 \\
\hline $\mathrm{E}$ & 0.012 & 0.05 & 0.016 & 0.039 & -0.001 & 0.017 & 0.025 & 0.016 & 0.019 & 0.002 & 0.001 & 0.079 \\
\hline $\mathrm{F}$ & -0.016 & 0.07 & 0.021 & 0.03 & 0.066 & 0.017 & 0.018 & 0.012 & 0.03 & 0.014 & -0.006 & 0.051 \\
\hline G & 0.03 & 0.329 & 0.006 & 0.353 & Nil & Nil & Nil & Nil & Nil & Nil & Nil & Nil \\
\hline $\mathrm{H}$ & 0.019 & 0.025 & 0.012 & -0.003 & Nil & Nil & Nil & Nil & Nil & Nil & Nil & Nil \\
\hline
\end{tabular}


Emir. J. Food Agric. 2010. 22 (2): 117-129

http://ffa.uaeu.ac.ae/ejfa.shtml

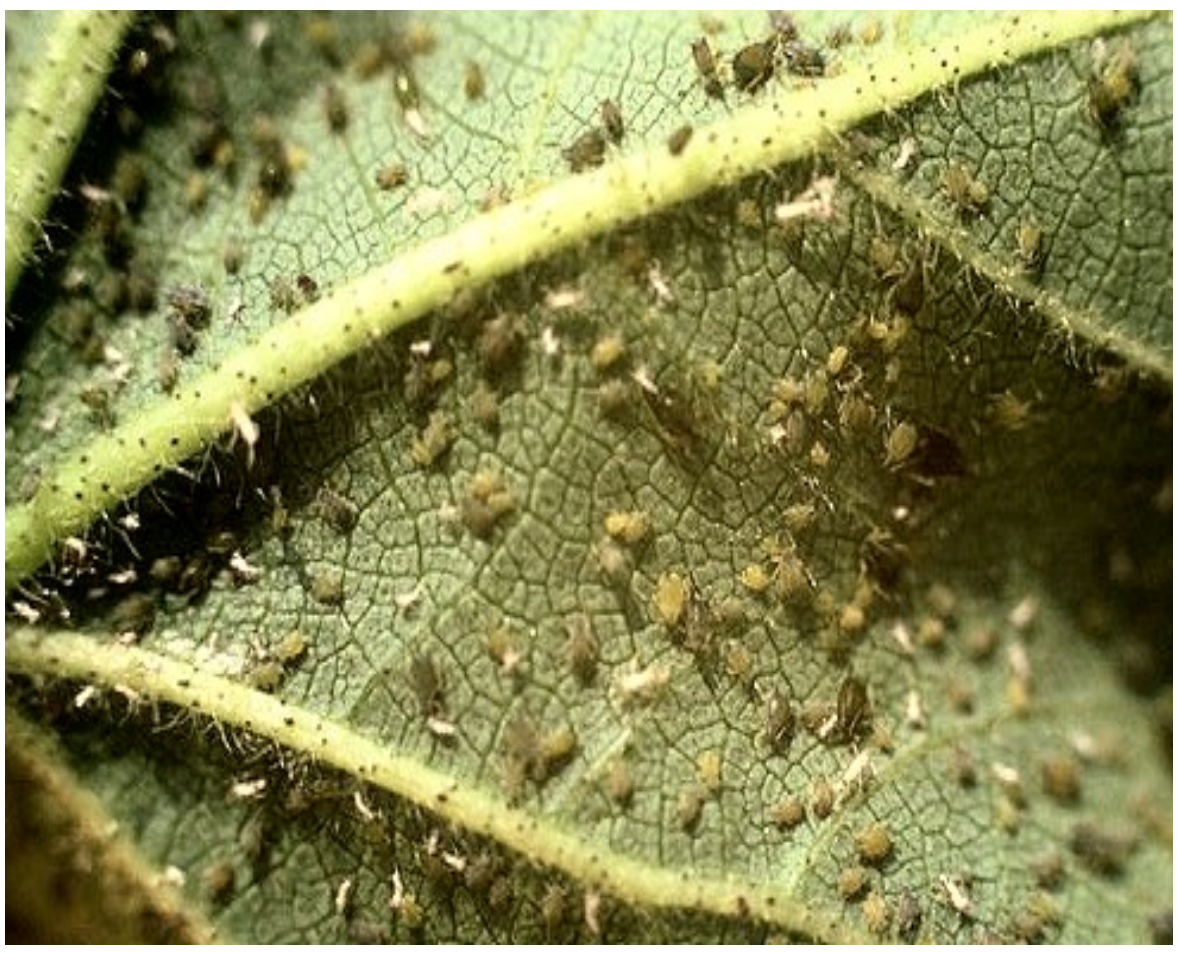

Figure 3. Transmission of CMV by Aphis gossypii into N. glutinosa.

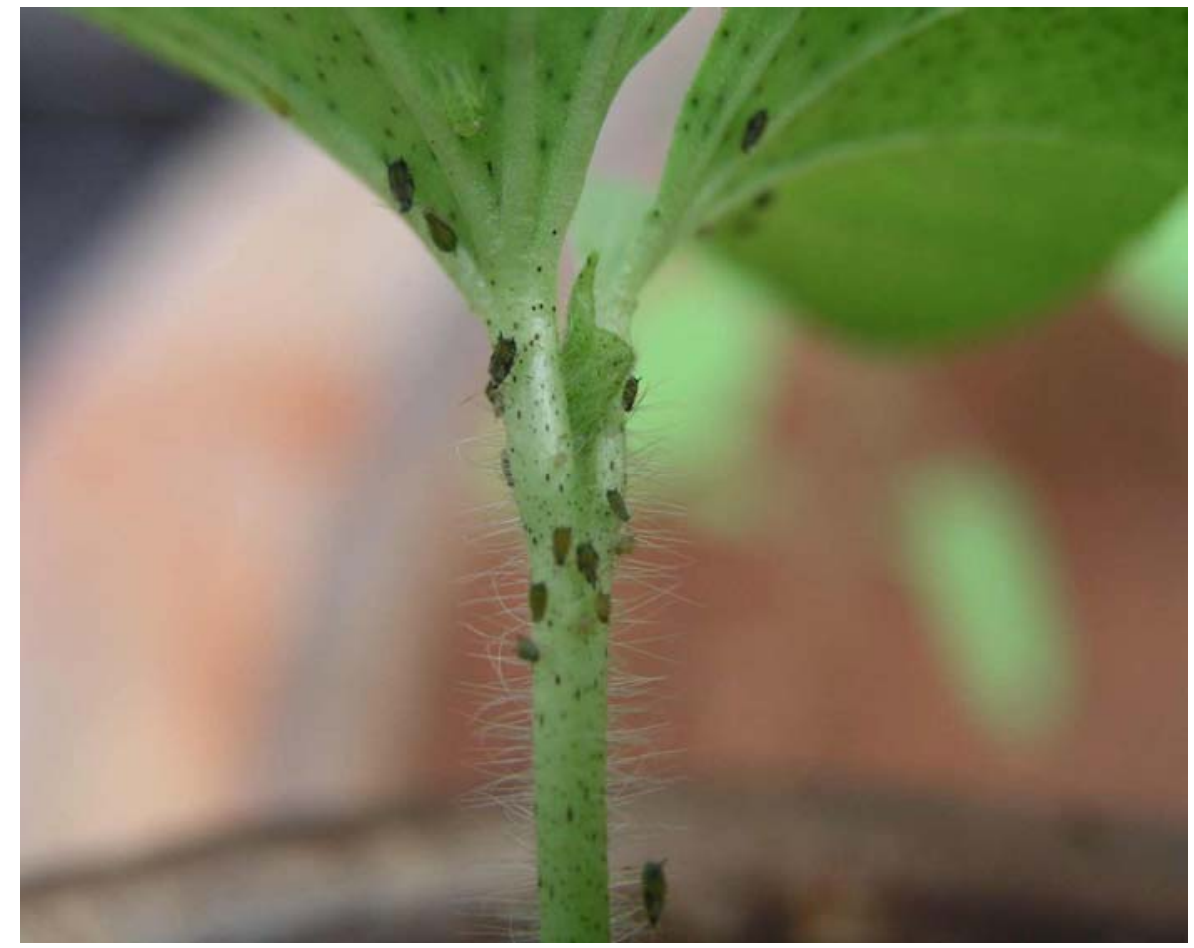

Figure 4. Transmission of CMV into $V$. ungulate by Aphis craccivora. 
R. Dheepa and S. Paranjothi

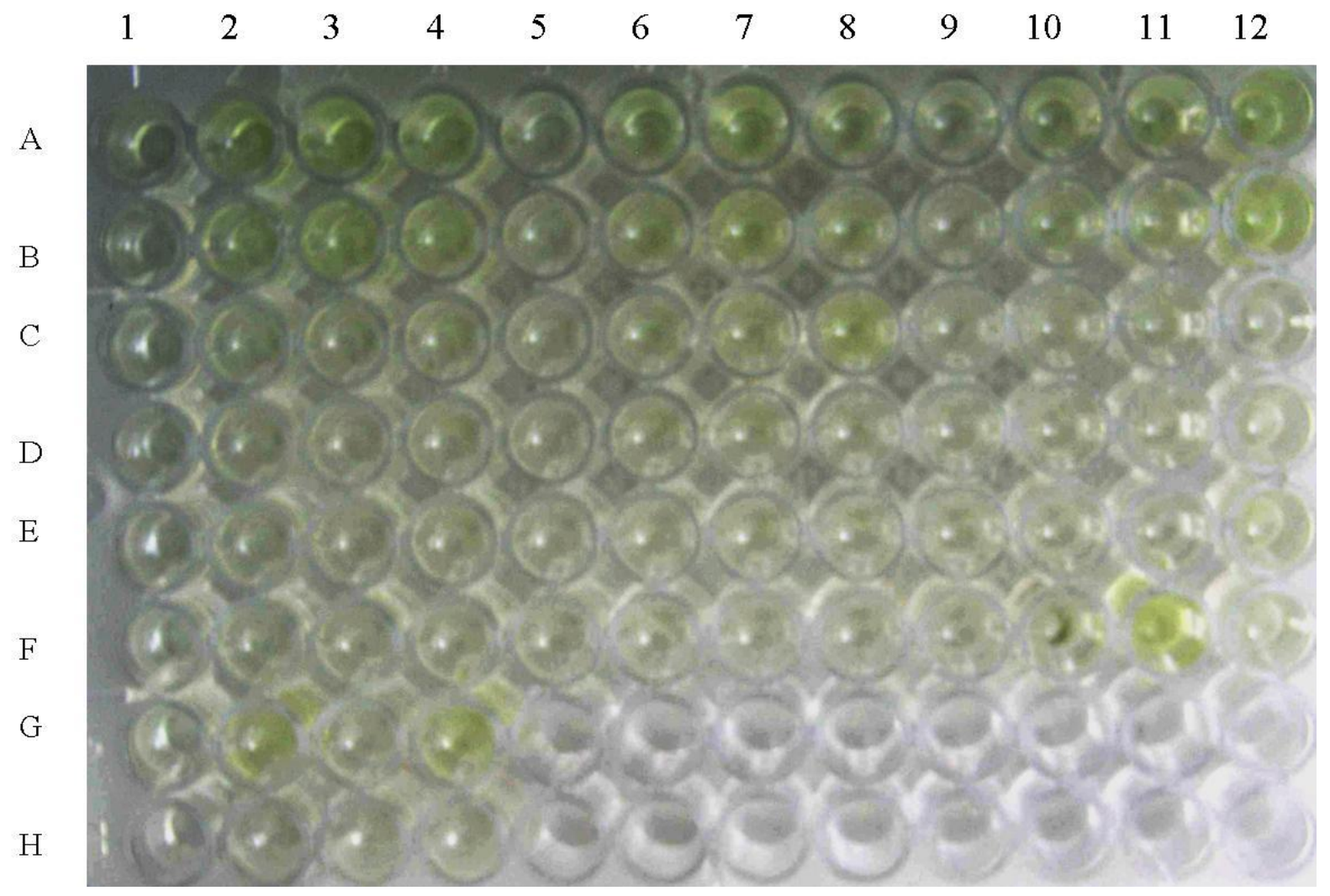

Figure 5. Detection of CMV from asymptomatic host plants through DAC-ELISA. Yellow colour - positive; No colour development - Negative.

\section{Acknowledgements}

The authors are thankful to Dr. R. Selvarajan, Senior Scientist, Molecular Virology Laboratory, National Research Center for Banana (NRCB), Indian Council of Agricultural Research, Tiruchirappalli, Tamil Nadu, India and thankful to Dr. Ishwar Bhat, Senior Scientist, IISR, Calicut, Kerala, India for kindly providing Cucumber Mosaic Virus antiserum.

\section{Reference}

Aglave, B. A. Krishnareddy, M. Patil and M. S. Andhale. 2007. Molecular Identification of a Virus Causing Banana Chlorosis Disease from Marathwada Region. Int. J. Biotechnol. Biochem. 3:13-23.
Bird, J and F. L. Wellman. 1962. A mosaic disease of Musacious crops in Puerto Rico. Pytopathol. 52:286.

Callinisan, M. R. 1938. The three destructive disease of abaca in Davo (Bunchy top, Mosaic and the vascular disease) and their control. Phillip. J. Agric. 9:329-333.

Clark, M. F. and B. Joseph. 1984. Enzyme Immuno Sorbent Assay in Plant Virology In: Methods in Virology, K. Maramorsch and Koprowski (Eds.), Academic Press, New York 7:51-85.

Dale, J. L. 1987. Banana bunchy top: An economically important tropical plant virus disease. Adv. Virus Res. 33:301-325.

Diekmann, D. R. and C. A. J. Putter. 1996. Musa, $2^{\text {nd }} \cdot$ FAO/I/PGR Technical 
Guidelines for the Safe Movement of Germplasm, No.15, FAO Rome IIPGRI Rome, pp.28.

Francki, R. I. B., D. W. Moscop and T. Hatla. 1979. CMV. CMI/AAB Description of plant viruses, No.213.

Gambley, C. F. and J. E. Thomas. 2001. Molecular characterization of banana mild mosaic virus: a new fi lamentous virus in Musa spp. Arch. Virol. 146: 1369-1379.

Hsu, H. T., L. Barzuan, Y. Hsu, H. Bliss, and K. L. Perry. 2000. Identification and subgrouping of Cucumber mosaic virus with mouse monoclonal antibodies. Phytopathol. 90:615-620.

Kaper, J. M. and H. E. Waterworth. 1981. Cucucomovirus. In Handbook of plant virus infections (Ed. E. Kurstak) Elsevier/North Holland: London, pp. 257-332.

Kiranmai, G., T. Sathyanarayana and P. Sreenivasulu. 1997. Molecular cloning and detection of cucumber mosaic cucumovirus causing infectious chlorosis of banana using DNA probes. Indian Phytopath. Soc. Golden Jublee Int. Conf. Nov. 10-15, 1997. New Delhi.

Lockhart, B. E. L. and D. R. Jones. 2000. Banana mosaic. In: Diseases of Banana, Abaca and Enset (Jones, D.R. Ed.), CABI publishing, UK, pp. 256-263.

Madhubala, R., V. Bhadramurthy, A. I. Bhat, P. S. Hareesh, S. T. Retheesh, and R. S. Bhai. 2005. Occurrence of Cucumber mosaic virus on vanilla (Vanilla planifolia Andrews) in India. J. Biosci. 30:339-350.
Magee, C. J. P. 1927. Investigation on the bunchy top disease of banana. Comm. Austr. Countries Sci. Ind. Res. Bull. 30, p. 64.

Magee, C. J. P. 1930. A new virus disease of banana. Agric. Gaz. N. S. W. 41:929.

Magee, C. J. P. 1940. Transmissions of infectious chlorosis or heart rot of the banana and its relationship to cucumber mosaic. J. Austr. Inst. Agric. Sci. 6:109-110.

Magnaya, L. V., R. V. Valmayor. 1995. BBTV, CMV and other viruses affecting banana in Asia and South Africa. Afr. Plant Prot. 2:1-8.

Mali, V. R and S. B. Rajegore. 1980. A cucumber mosaic virus disease of banana in India. Phytopath. Z. 98:127-136.

Mali, V. R. and G. D. Deshpande. 1976. Heart rot a virus disease of banana in Marathwada. Indian J. Mycol. P1. Path. 6:23-26.

Metha, P. R., N. C. Joshi, M. H. Rao and P. L. Renjhen. 1964. Bunchy top: A serious disease of banana in India. Sci. Cult. 30:259-263.

Palukaitis, P and F. Garcia-Arenal. 2003. Cucumber mosaic virus. Descriptions of Plant viruses. CMI/AAB, No. 400, $1-23$.

Patil, K. V. 1982. Further studies on cucumber mosaic virus causing banana mosaic virus causing banana mosaic or heart root disease. Ph.D. Thesis, Marathwada Agric. Univ. Parbhani p.104.

Raj, S. K., Aminuddin, K. M. Srivastva, and B. P. Singh. 1993. Natural 
infection of cucumber mosaic virus isolate on Dianthus babatus in India. Plant Pathol. 42:811-813.

Raj, S. K. A. Srivastava, G. Chandra and B. P. Singh. 2002. Characterisation of Cucumber mosaic virus isolate infecting Gladiolus cultivars and comparative analysis of serological and molecular methods for sensitive diagnosis. Curr. Sci. 83:1132-1136.

Raj, S. K., S. Kumar, D. Pratap, R. Vishnoi and S. K. Snehi. 2007. Natural Occurrence of Cucumber mosaic virus on Rauvolfia serpentina, a new record. Plant Disease 91:322.

Raj, S. K. S. Kumar and S. K. Snehi. 2008. First Report of Cucumber mosaic virus on Jatropha curcas in India. Plant Disease 92:171.

Rao, D. G.1980. Studies on a new strain of banana mosaic virus in South India. In: Proc. National Seminar on Banana Production Technology. C. R. Muthukrishnan and J. B. M. Abdul Khader (Eds.). Tamilnadu Agriculturual University, Coimbatore, India. pp.155-159.

Roossinck, M. J. 2002. Evolutionary history of Cucumber mosaic virus deduced by phylogenetic analayses. J. Virol. 76:3382-3387.

Samad, A., S. K. Raj, A. Srivastava, G. Chandra, P. V. Ajayakumar, M. Zaim and B. P. Singh. 2000. Characterization of a cucumber mosaic virus isolates infecting Egyptian henbane (Hyoscyamus muticus L.) in India. Acta Virol. 44:131-136.

Shukla, K. and P. Govinda. 2000. studies on aphid transmission of cucumber mosaic virus-pea strain. Indian Phytopathol. Soc. 2:930-932.
Silberschmidt, R. and N. R. Nobrega. 1941. Sobre Uma doenca de virus da bananeira. Biologico 7:216-219.

Simmonds, N. N. 1966. Banana, $2^{\text {nd }}$ Edition, Longman Publishers London.

Srivastava, K. M., S. K. Raj and B. P. Singh. 1992. Properties of a Cucumber Mosaic Virus strain naturally infecting Chrysanthemum in India. Plant Disease 76:474-476.

Sudhakar, N., D. Nagendra-Prasad, N. Mohan and K. Murugesan. 2006. First Report of Cucumber Mosaic Virus Subgroup II Infecting Lycopersicon esculentum in India. Plant Disease 90:1457.

Thomas, J. E. and R. G. Dietzgen. 1991. Purification, characterization and serological detection of virus -like particles associated with BBTD in Australia. J. Gen. Virol. 72:217-224.

Thomas, J. E., M. L. ISKra-Carana and D. R. Jones. 1994. BBTD Musa Disease Fact sheet N0.4, INIBAP, Montpillier, France, p.2.

Thomas, J. E., B. E. L. Lockhart and M. L. Iskra-Caruana. 2000. Banana mild mosaic virus. In: Diseases of banana, Abaca and Ensete, D. R. Jones (Ed.). CAB International, Wallingford, UK. Pp.275-279.

Verma, N., A. K. Singh, L. Singh, S. Kulshreshta, G. Raikhy, V. Hallan, R. Ram and A. A. Zaidi. 2004. Occurrence of Cucumber mosaic virus in Gerbera jamesonii form India. Plant Disease 88:1161.

Verma, N., B. K. Mahinghara, R. Ram and A. A. Zaidi. 2006. Coat protein sequence shows that Cucumber mosaic virus isolate from geraniums 
Emir. J. Food Agric. 2010. 22 (2): 117-129

http://ffa.uaeu.ac.ae/ejfa.shtml

(Pelargonium Sp.) belongs to subgroup II. J. Biosci. 31:47-56.

Zora Singh, R. A. C. Jones and M. G. K. Jones. 1995. Identification of CMV subgroup I isolates from banana plants affected by infectious chlorosis disease using RT-PCR. Plant Disease 79:713-716. 